\title{
Antiplasmodial diterpenoid alkaloid from Aconitum heterophyllum: Isolation, characterization, and UHPLC-DAD based quantification
}

Anmol, ${ }^{\mathrm{a}, \mathrm{b}}$ Surekha Kumari, ${ }^{\mathrm{a}, \mathrm{b}}$ Rakesh Kumar, ${ }^{\mathrm{a}, \mathrm{c}}$ Raman Singh, ${ }^{\mathrm{a}, \mathrm{b}}$ Gaurav Aggarwal, ${ }^{\mathrm{a}}$ Prakhar Agrawal, ${ }^{\mathrm{d}}$ Dinkar Sahal, ${ }^{\mathrm{d} *}$ Upendra Sharma ${ }^{\mathrm{a}, \mathrm{b}^{*}}$

${ }^{a}$ Chemical Technology Division, CSIR-Institute of Himalayan Bioresource Technology, Palampur, Himachal Pradesh 176061, India

${ }^{\mathrm{b}}$ Academy of Scientific and Innovative Research (AcSIR), Ghaziabad-201002, India

${ }^{\mathrm{c}}$ Wydział Chemii, Uniwersytet Wrocławski, 50-383 Wrocław, Poland

${ }^{\mathrm{d}}$ Malaria Drug Discovery Laboratory, International Centre for Genetic Engineering and Biotechnology, Aruna Asaf Ali Marg, New Delhi, 110067, India

\section{*Correspondence:}

Dr. Upendra Sharma, C-H Activation and Phytochemistry Group, Chemical Technology Division CSIR-IHBT, Palampur, Himachal Pradesh-176061, INDIA; E-mail: upendra@ihbt.res.in; upendraihbt@gmail.com; Tel.: +91-1894-230426 Fax: +91-1894-23043

Dr. Dinkar Sahal, Malaria Drug Discovery Laboratory, International Centre for Genetic Engineering and Biotechnology, Aruna Asaf Ali Marg, New Delhi, 110067, India; Email: dinkar@icgeb.res.in; dsahal@gmail.com, Phone: +91-11-26741007; Fax: +91-11-26162316 


\section{Abstract}

Aconitum heterophyllum is a traditionally important medicinal plant having numerous therapeutic actions as documented in Ayurveda. This plant has been used alone as well as in combination with other plants for the preparation of different anti-malarial formulations. However, there is no report on the assessment of its anti-plasmodial activity, and the compound responsible for this activity. The main aim of this study was to conduct phytochemical investigation of A. heterophyllum roots for the preparation of extract, fractions and isolation of pure molecules to identify active fractions/molecules responsible for the anti-plasmodial activity, and development of UHPLC-DAD based analytical method which can be used for the quantification of marker compounds in the extracts and fractions. Hydro-alcoholic extract (1:1 $\mathrm{v} / \mathrm{v}$ ) and fractions ( $n$-hexane, chloroform, ethyl acetate, $n$-butanol and water) were prepared from the dried powdered roots of A. heterophyllum. Fractions were further subjected to silica gel-based column chromatography to isolate pure specialized secondary metabolites from this plant. All extracts, fractions and pure molecules were evaluated against the chloroquine resistant $P f$ INDO and chloroquine sensitive $P f 3 \mathrm{D} 7$ strains in culture for calculating their $\mathrm{IC}_{50}$ values. UHPLC-DAD based analytical method was also developed for the first time for the quantification and quality assessment of this commercially important Himalayan medicinal plant. Phytochemical investigation of A. heterophyllum root led to the isolation of six specialized metabolites named as 2-O-cinnamoyl hetisine (1), atisinium (2), 4-oxabicyclo [3.2.2] nona-1(7),5,8-triene (3), atisinium cinnamate (4), aconitic acid (5), and atisinium formate (6). Compound $\mathbf{1}$ is a new hetisine type diterpenoid alkaloid, compounds $\mathbf{4}$ and $\mathbf{6}$ are new counter ionic forms observed with atisinium ion, and compound $\mathbf{3}$ is being reported for the first time from this genus. Chloroform fraction was found to be the most active with $\mathrm{IC}_{50}$ $(\mu \mathrm{g} / \mathrm{mL}) 1.01$ (Pf INDO) and 1.32 (Pf3D7). The isolated molecule 2-O-cinnamoyl hetisine (1), a new diterpenoid alkaloid isolated from chloroform fraction, showed promising 
antiplasmodial activities with $\mathrm{IC}_{50}(\mu \mathrm{M}) 1.92(P f$ INDO) and $10.8(P f$ 3D7). Activity of chloroform fraction was further validated by the developed UHPLC-DAD based method as the quantity of 2-O-cinnamoyl hetisine (1) was higher in the chloroform fraction $(\cong 200 \mu \mathrm{g} / \mathrm{mL})$ than in all other fractions $(<7 \mu \mathrm{g} / \mathrm{mL})$. Atisinium (2) and 2-O-cinnamoyl hetisine (1) were found to be the main marker compounds of this plant based on quantity and antiplasmodial activity, respectively. This study provides the scientific rational for the traditional use of this plant in treating malaria. Further, this study revealed that anti-malarial potential of this plant might be due to the presence of diterpenoid alkaloids.

\section{Abbreviation List}

API: Ayurvedic Pharmacopeia of India

COSY: Correlation spectroscopy

DAD: Diode-Array Detector

ESI: Electrospray Ionization

HRMS: High Resolution Mass Spectrometry

HMBC: Heteronuclear multiple bond correlation

HMQC: Heteronuclear multiple quantum correlation

NOESY: Nuclear Overhauser Effect Spectroscopy

LC: Liquid Chromatography

MS: Mass Spectrometry

NMR: Nuclear Magnetic Resonance

UV: Ultra violet

Keywords: Aconitum heterophyllum, diterpenoid alkaloids, antiplasmodial activity, quantification, quality assessment. 


\section{Introduction}

Ethnopharmacological potential of plants has been recognized since times immemorial as plants have proven to be the adroit craftsmen of bioactive molecules such as paclitaxel (Taxus brevifolia) against cancer, artemisinin (Artemisia annua) against malaria, silymarin (Silybum marianum) against liver diseases, and tiotropium a derivative of atropine (Atropa belladonna) against chronic pulmonary diseases (Veeresham 2012; Koparde et al., 2019). Since the beginning of $21^{\text {st }}$ century, modern world has been facing a serious health crisis caused by drug resistance leading to the acute need for new drug like molecules. Emergence of severe acute respiratory syndrome Corona Virus (SARS CoV) in 2003, H1N1 influenza virus pandemic in 2009, the middle east respiratory syndrome (MERS) in 2012, increasing cases of drug resistance and now the on-going global pandemic COVID-19 have shattered the emotional and economic well-being of human societies across the globe (Major Epidemics of the Modern Era, 2021; Suresh et al., 2020).

Malaria is a protozoan parasitic infection against which world has been fighting for long and the demand for effective, safe and affordable treatment has been rising (White 2004). According to world malaria report 2020,1.5 billion cases and 7.6 million global deaths were reported between 2000-2019 (World malaria report 2020) of which 229 million cases and 0.4 million deaths were reported in 2019 only. According to this report, in India although there has been reduction in malaria cases i.e., from 20 million cases in 2000 to 5.6 million in 2019, India still accounts for $86 \%$ of all malaria deaths in South-East Asia region (WHO 2020). Emergence of drug resistance offered by malaria parasite against currently available drugs has posed a serious threat towards global race of malaria eradication (White 2004). Resistance shown by P. falciparum strains has been regarded as major contributor for resurgence of malaria morbidity and mortality and some of the mutant strains have also been reported to be not detected by the rapid malaria diagnostic test (White 2004; Feleke et al., 2021). Scientific 
validation of traditionally known medicinal plants having anti-malarial potential can serve as valuable tool for providing new bioactive molecules (Holzmeyer et al., 2020 and Pascolutti et al., 2014). With this target and in continuation of our earlier work (Bhatt et al., 2020) on providing scientific evidences on traditional claims of anti-malarial potential of plants, herein we report anti-plasmodial potential of A. heterophyllum.

Genus Aconitum belonging to family Ranunculaceae consists of 300 different species scattered all over the world out of which 24 species are found in the Himalayan sub-alpine and alpine regions at altitudes ranging from 2500-4000 meters (Paramanick et al., 2017). Plants belonging to genus Aconitum are rich sources of structurally complex diterpenoid alkaloids with diverse pharmacological activities (Shen et al., 2018). Diterpenoid alkaloids are often termed as crypto/pseudo alkaloids as they originate from amination of natural tetracyclic diterpenes (Wang et al., 2002). Plants of this genus have been traditionally used for combating malaria, some of which are now scientifically validated (Wangchuk et al., 2010).

Aconitum heterophyllum, well known for its numerous medicinal uses, is a commercially important Himalayan medicinal plant locally known as Ativisha, Atees or Patish (Bora et al., 2021). According to the National Medicinal Plant Board (NMPB) of India, A. heterophyllum is among the highly prioritized medicinal plants having annual trade of 100-200 metric tons and is placed under subsidized plant category in India to promote its cultivation (https://nmpb.nic.in/content/prioritised-list-medicinal-plants-cultivation). According to the Ayurvedic Pharmacopoeia of India (API) which is a unique book comprising monographs of single plants as well as formulations (Joshi et al., 2017), this herb has various therapeutic uses such as in krimiroga (worm infestation), jvara (fever), kasa (respiratory tract disease), chardi (vomiting) and amatisara (diarrhoea) (API, 1989). There are many traditional claims on antimalarial potential of this plant (Ukani et al., 1996; Kour et al., 2016). According to API 'Sudarsana Churna', a mix of several medicinal herbs including A. heterophyllum is a well- 
known Ayurvedic formulation known to cure debilitating effects and fevers like malaria (API, 1989, Pelletier et al., 1968b; Wangchuk et al., 2010). Attempts have been made to scientifically validate some of the traditional medicinal claims of this plant and numerous bio-activities including abdominal distension, anti-alzheimer's disease, anti-bacterial, anti-diabetic, antidiarrheal, anti-helminthic, anti-inflammatory, anti-leucorrhea, anti-oxidant, anti-ulcer, aphrodisiac, arthritis, hypolipidemic, immunomodulatory, nephroprotective, antipyretic, antimicrobial, analgesic, antifungal, insecticidal and antiviral have been reported (Jabeen et al., 2006, Malhotra et al., 2021; Bora et al., 2021). However, despite being a rich source of structurally complex molecules, most of the activities listed above have been performed on crude extracts and partially purified fractions alone (Bora et al., 2021).

Phytochemical studies on A. heterophyllum have revealed the presence of structurally complex molecules such as atisine, aconitic acid, hetisine, heteratisine, benzoylheteratisine, atidine, Fdihydroatisine, hetidine, hetisone, heterophyllisine, heterophylline, heterophyllidine, 6dehydroacetylsepaconitine, 13-hydroxylappaconitine, heterophyllinine-A, heterophyllinine$\mathrm{B}$, lycoctonine, delphatine, lappaconitine, $6 \beta$-Methoxy $9 \beta$-dihydroxylheteratisine, $1 \alpha, 11,13 \beta$ trihydroxylhetisine, 6,15 $\beta$-dihydroxylhetisine, iso-atisine, hetisinone and 19-epi-isoatisine (Pelletier et al., 1968a; Nagarajan et al., 2015; Ahmad et al., 2017; Malhotra et al., 2021; Bora et al., 2021).

There have been numerous reports where the much cheaper look alike roots of Cyperus rotundus and Cryptocoryne spiralis (Nagarajan et al., 2015) have been used as adulterants and sold in the name of $A$. heterophyllum. Because of such demand and importance, there is need of complete phytochemical investigation, quality control method development and biological activity evaluations for this plant. With this aim, the present study is focused on (a) extraction, fractionation and isolation of specialized metabolites present in the roots of this plant, (b) evaluation of anti-plasmodial activity to validate traditionally claimed anti-malarial potential, 
(c) development of UHPLC-DAD based quality control method for quantification of isolated molecules.

\section{Material and Methods}

\subsection{Plant Material}

Roots of A. heterophyllum were collected from Chamba, HP (alt. 2500 m) in September 2019. The plant material was identified by a taxonomist at CSIR-IHBT, Palampur and a voucher specimen no. (PLP 18559) was submitted to the herbarium of CSIR-IHBT, Palampur, HP176061, India. The collected plant material was shade dried at room temperature and the dried plant material was grinded in MAC Willy mill, PLT 210 grinder to get uniform powder suitable for extraction.

\subsection{Chemicals and reagents}

Methanol and water (LC grade) were purchased from J. T. Baker (Mallinckrodt Baker Inc., St. Louis, MO, USA) while chloroform and formic acid were obtained from S. D. Fine Chemicals Ltd. (Mumbai, India). For column chromatography, silica gel (230-400 and 60-120 mesh) from Merck was used. TLC analysis was performed on Merck aluminium base silica gel $60 \mathrm{~F}_{254}$ sheets. For UHPLC, three standards ferulic acid (S1), lappaconitine (S2) and cinnamic acid (S3) were used. S1 and S3 were purchased from Sigma-Aldrich whereas $\mathbf{S 2}$ was procured from TCI. Other molecules including 2-O-cinnamoyl hetisine (1), atisinium (2) and aconitic acid (5) used as standards for analytical method development were isolated in current study with purity $>90 \%$ calculated on the basis of UHPLC-DAD analysis.

\subsection{Preparation of Extract and Fractions}

Dried roots of $A$. heterophyllum $(2.6 \mathrm{Kg})$ were extracted thrice with ethanol: water $(1: 1 \mathrm{v} / \mathrm{v}$, $8 \mathrm{Lx} 3)$ at room temperature by sonication $\left(30 \mathrm{~min} ; 40^{\circ} \mathrm{C}\right)$ followed by percolation $(12 \mathrm{~h} \times 3)$. The percolate was dried in rotary evaporator at $50^{\circ} \mathrm{C}$ to obtain $353.0 \mathrm{~g}(13.57 \% \mathrm{w} / \mathrm{w})$ of hydro- 
alcoholic extract. The hydro-alcoholic extract (303.0 g) was dissolved in 2Liters of distilled water and sequentially partitioned with $n$-hexane, chloroform, ethyl acetate and $n$-butanol (500 mL x 3 for each solvent) to obtain $n$-hexane (270 mg; oil), chloroform (3.12g, solid) ethyl acetate (2.08g, solid), $n$-butanol $(63.50 \mathrm{~g}$, solid) and water (152.40 g solid) fractions (Fig. 1).

\subsection{Isolation of Pure Compounds}

The chloroform fraction (CF; $2.6 \mathrm{~g}$ ) was subjected to normal phase column chromatography over silica gel (60-120 mesh) and eluted with $\mathrm{MeOH}-\mathrm{CHCl}_{3}(\mathrm{M} / \mathrm{C})$ to yield five $\boldsymbol{S F} \boldsymbol{S}$ CF-1 (425 $\mathrm{mg} ; 5-20 \% \mathrm{M} / \mathrm{C}), \mathrm{CF}-2$ (251 mg; $25 \% \mathrm{M} / \mathrm{C}), \mathrm{CF}-3$ (625 mg; $30 \% \mathrm{M} / \mathrm{C}), \mathrm{CF}-4$ (376 mg; 50\% M/C) and CF-5 (90 mg; pure methanol). Sub fraction (SF) CF-3 (625 mg) was further subjected to normal phase column chromatography over silica gel (230-400 mesh) and eluted with $\mathrm{MeOH}-\mathrm{CHCl}_{3}+\mathrm{HCOOH}(0.1 \% \mathrm{v} / \mathrm{v})$ to get compound $1(16 \mathrm{mg})$ at $5 \%$ methanol. Likewise, SF CF-4 (376 mg) was subjected to normal phase column chromatography over silica gel (230400 mesh) with $\mathrm{MeOH}-\mathrm{CHCl}_{3}+\mathrm{NH}_{3}(0.1 \% \mathrm{v} / \mathrm{v})$ which yielded compound $2(12 \mathrm{mg})$ at $50 \%$ methanol.

The ethyl-acetate fraction (EF; $2.08 \mathrm{~g}$ ) was also subjected to normal phase column chromatography over silica gel (60-120 mesh) using $\mathrm{MeOH}-\mathrm{CHCl}_{3}(\mathrm{M} / \mathrm{C})+\mathrm{HCOOH}(0.1 \%$ v/v) as eluent to yield nine $\boldsymbol{S F}$ s EF-1 (198 mg; 1\% M/C), EF-2 (243 mg; $2 \%$ M/C), EF-3 (409 $\mathrm{mg} ; 5 \% \mathrm{M} / \mathrm{C}), \mathrm{EF}-4$ (619 mg; 10\% M/C), EF-5 (250 mg; 15\% M/C), EF-6 (99 mg; 20\% M/C) , EF-7 (178 mg; 25\% M/C) , EF-8 (260 mg; 50\% M/C), EF-9 (39 mg; pure methanol). SF EF4 (619 mg) was subjected to normal phase column chromatography over silica gel (230-400 mesh) with $\mathrm{MeOH}_{-} \mathrm{CHCl}_{3}(\mathrm{M} / \mathrm{C})+\mathrm{HCOOH}(0.1 \% \mathrm{v} / \mathrm{v})$ which further provided $\boldsymbol{S F}$ sF-4-1 (80 mg; 5-20 \% M/C), EF-4-2 (125 mg; 20-50\% M/C), EF-4-3 (98-mg; 75\% M/C), EF-4-4 (143 mg; pure methanol). SF EF-4-2 (125 mg) was subjected to C-18 reverse phase column chromatography using $\mathrm{MeOH}-\mathrm{H}_{2} \mathrm{O}(\mathrm{M} / \mathrm{W})+\mathrm{HCOOH}(0.1 \% \mathrm{v} / \mathrm{v})$ solvent system to get compound 3 (14 $\mathrm{mg}$ ) at 50\% methanol. 
Similarly, the $n$-butanol fraction (BF; $61.7 \mathrm{~g}$ ) was subjected to normal phase column chromatography over silica gel (60-120 mesh) by using $\mathrm{MeOH}-\mathrm{CHCl}_{3}(\mathrm{M} / \mathrm{C})$ to get eight $\boldsymbol{S F} \boldsymbol{s}$ BF-1 (759 mg; pure $\left.\mathrm{CHCl}_{3}\right), \mathrm{BF}-2(2.1 \mathrm{~g} ; 10 \% \mathrm{M} / \mathrm{C}), \mathrm{BF}-3$ (25.9 g; 20\% M/C), BF-4 (7.8 g; 25\% M/C), BF-5 (5.8 g; 30\% M/C), BF-6 (1.6 g; 50\% M/C), BF-7 (1.2 g; 75\% M/C), BF-8 (1.09 g; pure MeOH). SF BF-3 (25.9 g) was subjected to normal phase column chromatography by silica gel $\left(60-120\right.$ mesh) with $\mathrm{MeOH}-\mathrm{CHCl}_{3}(\mathrm{M} / \mathrm{C})+\mathrm{NH}_{3}(0.1 \% \mathrm{v} / \mathrm{v})$ as solvent system which yielded eight $\boldsymbol{S F}$ s BF-3-1(1.20 g; 5\% M/C), BF-3-2(2.40 g; 10\% M/C), BF-3-3(5.05g; $20 \% \mathrm{M} / \mathrm{C}), \mathrm{BF}-3-4(3.20 \mathrm{~g} ; 25 \% \mathrm{M} / \mathrm{C}), \mathrm{BF}-3-5(1.80 \mathrm{~g} ; 30 \% \mathrm{M} / \mathrm{C}), \mathrm{BF}-3-6(3.50 \mathrm{~g} ; 20 \% \mathrm{M} / \mathrm{C})$, BF-3-7(4.10g; 75\% M/C) and BF-3-8(0.50 mg; pure MeOH). Out of them, the $\boldsymbol{S F}$ BF-3-3 (5.05 g) which was eluted at $20 \% \mathrm{M} / \mathrm{C}$ was further subjected to column chromatography using silica gel (230-400 mesh) and eluted using previous solvent system to obtain five more $\boldsymbol{S F}$ S (BF-33-1 to BF-3-3-5). Out of these five, $\boldsymbol{S F}$ BF-3-3-3 (1.8 g; eluted at 20\% $\left.\mathrm{M} / \mathrm{C}+\mathrm{NH}_{3}(0.1 \% \mathrm{v} / \mathrm{v})\right)$ was packed in normal phase column by taking $\mathrm{MeOH}-\mathrm{CHCl}_{3}$ solvent system which yielded compound 4 (9 mg) at $15 \%$ methanol. SF BF-5 (5.8 g) was subjected to normal phase column chromatography using silica gel (230-400 mesh) by taking $\mathrm{MeOH}-\mathrm{CHCl}_{3}(\mathrm{M} / \mathrm{C}): \mathrm{HCOOH}(0.1$ $\% \mathrm{v} / \mathrm{v})$ solvent system in increasing order of polarity which yielded 5 SF $\mathrm{s}$ BF-5-1 (1.2g; 5-10 $\% \mathrm{M} / \mathrm{C}), \mathrm{BF}-5-2$ (750 mg; $20 \% \mathrm{M} / \mathrm{C}), \mathrm{BF}-5-3$ (2.1 g; 25\% M/C), BF-5-4 (403 mg; 50\% M/C), BF-5-5 (340 mg; pure MeOH). SF BF-5-2 (750 mg) was subjected further to chromatography using the same conditions which yielded compound 5 (35 mg) at $25 \%$ of M/C. SF BF-6 (1.6 g) was further subjected to normal phase column chromatography using silica gel (230-400 mesh) by taking $\mathrm{MeOH}-\mathrm{CHCl}_{3}(\mathrm{M} / \mathrm{C})$ solvent system which yielded four $\mathbf{S F}$ BF-6-1(367 mg; 10\% M/C), BF-6-2(220 mg; 25\% M/C), BF-6-3(120 mg; 50\% M/C) and BF-6-1(192 mg; pure MeOH). SF BF-6-3 (120 mg; eluted at 50\% M/C) provided compound 6 (17 mg) after normal phase column chromatography over silica gel (230-400 mesh) with pure methanol as eluent (Fig.1). 


\subsection{Characterization of isolated compounds}

Melting points were recorded on a Bronsted Electro thermal 9100. All isolated compounds were characterized by NMR, LC-MS, IR and UV-Vis spectroscopies. Nuclear magnetic resonance spectra were recorded on a Bruker-Avance $600 \mathrm{MHz}$. Mass spectra were recorded on Water Q-ToF-Micro Micromass and high-resolution 6560 Ion Mobility Q-TOF LC/MS (Agilent, Santa Clara, USA). IR was analysed by Shimadzu IR Prestige-21with ZnSe single reflection ATR accessory. UV-Vis analysis was carried out on Shimadzu UV-VIS spectrometer-2600. Optical rotations were measured on Anton Parr MCP 100 Modular Circular Polarimeter. All NMR (1-D for all molecules and 2-D for new molecules), IR and UV spectra for all pure compounds is attached in the supporting information.

\subsection{In vitro Plasmodium falciparum culture}

Plasmodium falciparum strains were obtained from BEI Resources (MR4) and were cultured using the method of Trager and Jensen 1976. Cultures were maintained in $\mathrm{O}^{+v e} \mathrm{RBCs}$ (collected from rotary blood bank, New Delhi) at 4\% haematocrit in RPMI 1640 media supplemented with $2 \%$ sodium bicarbonate, $0.5 \%$ Albumax I, $50 \mathrm{mg} / \mathrm{L}$ hypoxanthine and $20 \mathrm{mg} / \mathrm{L}$ gentamicin. The culture plates were incubated at $37^{\circ} \mathrm{C}$ under a gas mixture $5 \% \mathrm{O}_{2}, 5 \% \mathrm{CO}_{2}$, and $90 \% \mathrm{~N}_{2}$.

\subsection{Measurement of in vitro inhibition of P. falciparum growth}

Laboratory adapted Plasmodium falciparum strains Pf3D7 (CQ sensitive) and PfINDO (CQ resistant) were used to evaluate antiplasmodial activity of extracts and pure molecules. Assay was performed in 96 well format using CQ (zero growth-positive control), $0.4 \%$ DMSO (100\% growth, negative control) and test samples ( 0 to $100 \mu \mathrm{g} / \mathrm{ml}$ for extracts and 0 to $100 \mu \mathrm{M}$ for pure molecules) in a final well volume of $100 \mu \mathrm{L}$ of sorbitol synchronized ring stage culture at $2 \%$ haematocrit and $1 \%$ parasitemia. Plates were incubated under reduced $\mathrm{O}_{2}$ condition for 72 
$\mathrm{h}$ followed by measurement of growth using SYBR Green I fluorescence-based method (Smilkstein et al., 2004) using a 96-well fluorescence plate reader (Victor, Perkin-Elmer), with excitation and emission wavelengths of 480 and $535 \mathrm{~nm}$, respectively. Thereafter, 50\% inhibitory concentration ( $\left.\mathrm{IC}_{50}\right)$ was determined by analysis of dose-response curves using nonlinear regression using the IC Estimator-version 1.2 software (http://www.antimalarialicestimator.net/MethodIntro.htm) (Free Software Foundation, Boston, MA, USA).

\subsection{Measurement of in vitro cytotoxicity against mammalian cell line}

Cytotoxicity of extracts, fractions and isolated compounds were assessed by MTT (3-(4,5dimethylthiazol-2-yl)-5-(3-carboxymethoxyphenyl)-2-(4-sulfophenyl)-2H-tetrazolium) cell viability assay (Mosmann, 1983). HEK293 and HUH 7 cells were cultured in DMEM (Dulbecco's Modified Eagle's Medium) supplemented with $10 \%$ foetal bovine serum (FBS) and $4 \% \mathrm{NaHCO}_{3}$ until full confluence was achieved. Trypsin detached cells $\left(10^{4}\right.$ cells / 200 $\mu \mathrm{l})$ were thereafter seeded into 96 -well plates in triplicates. The plates were then incubated in $5 \% \mathrm{CO}_{2}$ humidified atmosphere for 12 to $16 \mathrm{hr}$ at $37^{\circ} \mathrm{C}$. After $16 \mathrm{~h}$, spent media was replaced with fresh cDMEM $(100 \mu \mathrm{L})$ containing extracts or purified metabolites, (0 to $400 \mu \mathrm{g} / \mathrm{ml}$ for extracts and 0 to $400 \mu \mathrm{M}$ for pure molecules) followed by $24-\mathrm{hr}$. incubation at $37^{\circ} \mathrm{C}$ in a humidified $5 \% \mathrm{CO}_{2}$ atmosphere. $10 \%$ DMSO (v/v) and $0.8 \%$ DMSO (v/v) served as zero growth and full growth controls respectively. $20 \mu \mathrm{L}$ of MTT stock (5 mg/ml in 1x PBS) was added to each well and plate was incubated in dark for $3 \mathrm{hr}$ at $37^{\circ} \mathrm{C}$. At the end of the incubation period, $120 \mu \mathrm{L}$ \{corresponding to the amount of MTT $(20 \mu \mathrm{L})+100 \mu$ l of drugs in DMSO/cDMEM $\}$ was aspirated out. Then, DMSO $(200 \mu \mathrm{L})$ was added to each well to dissolve the formazan crystals formed. Formation of formazan, an index of cell growth was measured at $570 \mathrm{~nm}$ using a microplate reader (Versa Max). $\mathrm{CC}_{50}$ values were computed by analysis of dose-response curves using non-linear regression using the IC Estimator-version 1.2 software (http://www.antimalarial-icestimator.net/MethodIntro.htm) (Free Software Foundation, 
Boston, MA, USA). Selectivity index (SI) was calculated as $\mathrm{CC}_{50} \mathrm{HEK} / \mathrm{IC}_{50}$ Parasite or $\mathrm{CC}_{50}$ HUH/IC 50 Parasite.

\subsection{Sample and standard solution preparation for UHPLC Analysis}

Parent extract and fractions were dissolved in LCMS grade methanol and subjected to sonication followed by filtration using $0.22 \mu \mathrm{M}$ PTFE syringe filter. Isolated molecules 2-Ocinnamoyl hetisine (1), atisinium (2), aconitic acid (5) and purchased standards ferulic acid (S1), lappaconitine (S2) and cinnamic acid (S3) (Fig. 2.) were accurately weighed to prepare stock solution $(1.0 \mathrm{mg} / \mathrm{mL})$ of each compound. Mixture of standard solution was prepared by taking $200 \mu \mathrm{L}$ from each stock solution. Standard mixture solution was serially diluted with HPLC grade methanol to achieve twelve different concentrations in the range 0.04-83.33 $\mu \mathrm{g} / \mathrm{mL}$ for plotting calibration curves.

\subsection{UHPLC-DAD conditions}

SHIMADZU NEXERA X-2 LC-30 AD (Shimadzu, Kyoto, Japan) based UHPLC system coupled with PDA detector was used for quantitative analysis of compounds isolated from roots of A. heterophyllum. The separation of compounds was achieved through Shimadzu shimpack-GIST C18 column $(2.1 \mathrm{~mm} \times 100 \mathrm{~mm}, 2 \mu \mathrm{m}$ particle size $)$ with column temperature at $30^{\circ} \mathrm{C}$. Mobile phase for quantitative analysis consisted of $0.1 \%$ formic acid/ water as solvent $\mathrm{A}$ and acetonitrile as solvent $\mathrm{B}$, with a linear gradient programmed as: $0.0-0.10 \mathrm{~min}, 5 \% \mathrm{~B}$; 0.10-15.0 min, $5 \%$ B; 15.0-17.0 min, $27 \%$ B; 17.0-20.0, 35\% B; 20.0-21.0, 46\% B; 21.0-22.0 $\min , 51 \% \mathrm{~B} ; 22.0-22.50 \mathrm{~min}, 56 \% \mathrm{~B}, 22.50-30.0 \mathrm{~min}, 5 \% \mathrm{~B}$. The flow rate was $0.3 \mathrm{~mL} / \mathrm{min}$ and the injection volume was $2 \mu \mathrm{L}$. Detection wavelengths (nm) selected for standards were 198 for atisinium (2), 212 for aconitic acid (5), 280 for 2- $O$-cinnamoyl hetisine (1) \& cinnamic acid (S3), 306 for lappaconitine (S2) and 322 for ferulic acid (S1).

\subsection{UHPLC-DAD method validation}


Following the ICH guidelines, linearity, limit of detection (LOD), limit of quantification (LOQ), precision and recovery were determined for validation of the developed UHPLC-DAD method. For the calibration curve, five to twelve dilutions of standard mixtures were prepared and finally graph was plotted by taking peak area vs concentration for each standard. Further up to 14 dilutions were used in order to calculate LOD and LOQ. The LOD was determined by taking signal-to-noise $(\mathrm{S} / \mathrm{N})$ ratio of about 3 whereas LOQ was determined at $\mathrm{S} / \mathrm{N}$ ratio of 10 . In order to determine the repeatability and reproducibility of developed method, intra-day and inter-day variations were measured. The number of replicates were 6 for intra-day variation measurement and one each for three consecutive days. In order to determine the accuracy of developed method, recovery test was performed. Known amounts of standard solutions at four different concentrations were spiked to evaluate recovery. The recoveries were determined by the formula: recovery $(\%)=($ detected amount - original amount $) /$ spiked amount $\times 100$ and finally average recovery of all four concentrations was calculated.

\section{Results}

\subsection{Characterization of Isolated compounds}

Compound 1 was isolated as a white powder which gave positive Dragendorff's test. The molecular formula was deduced as $\mathrm{C}_{29} \mathrm{H}_{33} \mathrm{NO}_{4}$ with positive HRESI-QTOF-MS exhibiting a molecular ion peak at $m / z 460.2480[\mathrm{M}+\mathrm{H}]^{+}$(calculated 460.2482). NMR spectra of compound 1 displayed terminal methylene group at $\delta_{H} 4.87(\mathrm{H}-17 \mathrm{a})$ and $4.72(\mathrm{H}-17 \mathrm{~b}) ; \delta_{C} 108.6(\mathrm{C}-17)$, methyl proton at $\delta_{H} 1.21(\mathrm{H}-18) ; \delta_{C} 29.1(\mathrm{C}-18)$, two oxygenated methines at $\delta_{H} 4.29(\mathrm{H}-11)$; $\delta_{C} 75.7(\mathrm{C}-11)$ and $\delta_{H} 4.15(\mathrm{H}-13) ; \delta_{C} 71.9(\mathrm{C}-13)$ (Table 1). In addition, there was another deshielded oxygenated proton at $\delta_{H} 5.31(\mathrm{H}-2) ; \delta_{C} 70.6(\mathrm{C}-2)$ due to attachment of cinnamoyl group at C-2. Cinnamoyl group was further confirmed with two trans protons $\delta_{H} 7.71(\mathrm{H}-23, \mathrm{~J}$ 
$=16.0 \mathrm{~Hz}) ; \delta_{C} 146.4(\mathrm{C}-23)$ and $\delta_{H} 6.63(\mathrm{H}-22, J=15.6 \mathrm{~Hz}) ; \delta_{C} 119.4(\mathrm{C}-22)$. Carbon and DEPT spectra revealed presence of six methylene, sixteen methine, one methyl and six quaternary carbons. These NMR signals were in expected range of hetisine C-20 diterpenoid alkaloids which were further confirmed by HSQC, HMBC, and COSY spectra (Huang et al., 2020). Carbonyl carbon of cinnamic acid group $\delta_{C} 167.5$ (C-21) showed HMBC correlation with $\delta_{H} 5.31(\mathrm{H}-2)$ which confirmed the attachment of cinnamoyl group at C-2 (Fig. 3). Based on this, compound $\mathbf{1}$ was identified as 2-O-cinnamoyl hetisine. Relative configuration of compound 1 was established by analysing coupling constants and NOESY correlations and comparison with literature reports (Huang et al., 2020; Lin et al., 2014). NOESY correlation of H3-18 with H-5, H-6, H-3 and H-13 (Fig. 3) depicted the $\beta$-orientation for methyl protons on the basis of literature (Lin et al., 2014). Further correlation between H-3 \& H-2, H-2 \& H-1, H-1 \& H-20, H-5 \& H-11, H-11 \& H-9 confirmed the $\beta$-orientation of these protons. $\alpha-$ Orientation of hydroxyl group at C-11 and C-13 was further confirmed by appearance of broad doublet and high coupling constant value $(J=9 \mathrm{~Hz})$ (Lin et al., 2014).

Compound 2 was isolated as a white powder giving positive Dragendorff's test. The molecular formula was deduced as $\mathrm{C}_{22} \mathrm{H}_{34} \mathrm{NO}_{2}{ }^{+}$with positive HRESI-QTOF-MS exhibiting a molecular ion at $\mathrm{m} / \mathrm{z} 344.2582[\mathrm{M}]^{+}$(calculated 344.2579 ). ${ }^{1} \mathrm{H}$ and ${ }^{13} \mathrm{C}$ spectras clearly indicated the presence of terminal methylene group at $\delta_{H} 5.11(\mathrm{H}-17 \mathrm{a})$ and $\delta_{H} 5.07(\mathrm{H}-17 \mathrm{~b}) ; \delta_{C} 110.5(\mathrm{C}-$ 17), and one tertiary methyl group at $\delta_{H} 1.08(\mathrm{H}-18) ; \delta_{C} 25.0(\mathrm{C}-18) .{ }^{1} \mathrm{H}$ and ${ }^{13} \mathrm{C}$ spectras also indicated one oxygenated methine proton at $\delta_{H} 3.70(\mathrm{H}-15) ; \delta_{C} 76.0(\mathrm{C}-15)$ and one methylene proton at $\delta_{H} 4.07-4.02(\mathrm{H}-22 \mathrm{a})$ and $\delta_{H} 3.97(\mathrm{H}-22 \mathrm{~b}) ; \delta_{C} 58.7(\mathrm{C}-22) .{ }^{13} \mathrm{C}$ DEPT, HSQC and mass spectra revealed the presence of one methyl carbon (position 4), twelve methylene carbons (positions 1, 2, 3, 6, 7, 11, 13, 14, 17, 19, 21 and 22), five methine carbons (positions 5, 9, 12, 15 and 20) and four quaternary carbons (positions 4, 8, 10 and16) which indicated the atisine type C-20 diterpenoid alkaloid (Pelletier et al., 1979; Shen et al., 2020). Complete planar 
structure of molecule was further verified by HSQC, HMBC, and COSY correlations (Pelletier et al., 1979; Xu et al., 2016). In addition to the resonance value at C-4 $\left(\delta_{C} 34.5\right)$, the values for C-10 $\left(\delta_{C} 47.5\right), \mathrm{C}-20\left(\delta_{H} 8.77 ; \delta_{C} 184.1\right)$ and C-21 $\left(\delta_{H} 4.27\right.$ and $\left.4.18 ; \delta_{C} 65.1\right)$ strongly indicated the existence of a quaternary $N$-centre in the molecule (Xu et al., 2016).

Similar spectral data was observed for compounds $\mathbf{4}$ and $\mathbf{6}$ except the presence of cinnamate and formate as counter anions, respectively. These are new ionic forms observed with atisinium cation as confirmed by NMR analysis. Cinnamoyl group in compound $\mathbf{4}$ was confirmed by two trans protons $\delta 7.36(\mathrm{~d}, J=16.0 \mathrm{~Hz}, 1 \mathrm{H})$ and $6.48(\mathrm{~d}, J=16.0 \mathrm{~Hz}, 1 \mathrm{H})$. Resonance values at $\delta_{H} 8.49$ and $\delta_{C} 170.6$ were observed for formate hydrogen and carbon, respectively in compound 6. It is noteworthy that no HMBC correlation was observed between cinnamate and formate part of counter ion with parent atisinium ion. Furthermore, presence of quaternary- $N$ centre in atisinium ion clearly depicted in NMR also supported the presence of the negatively charged counterions. However, for molecule 2 no counter ion was observed in NMR hence it is named as atisinium ion. Different counter ions are known to influence structure i.e., conformation, stability, solubility, physicochemical and biological property of molecules (Sikora et al., 2020). Detailed NMR data for compounds $\mathbf{2 , 4}$ and $\mathbf{6}$ is shown in supplementary information (Table S1).

Compound $\mathbf{3}$ and $\mathbf{5}$ were identified as 4-Oxabicyclo [3.2.2] nona-1(7),5,8-triene and aconitic acid, respectively after comparison of spectral data with reported literature (Govindan et al., 2019; Dona et al., 2016; Yin at al., 2019).

2-O-cinnamoyl hetisine (1): Brown powder; melting point $190-192{ }^{\circ} \mathrm{C} ;[\alpha] \mathrm{D}^{20}:-213.33(\mathrm{c} 0.03$, $\mathrm{MeOH}) . \mathrm{UV} / \mathrm{Vis} \lambda_{\max } \mathrm{nm}, \mathrm{MeOH}\left(\varepsilon ; \mathrm{M}^{-1} \mathrm{~cm}^{-1}\right): 278(179.93)$ and 204 (229.95). IR (ZnSe) $v_{\max }$ $\left(\mathrm{cm}^{-1}\right): 3348,2924,1703,1635,1579,1450,1313,1172,1074,1028,985,877,767,684 .{ }^{1} \mathrm{H}$ NMR (600 MHz, CD 3 OD) and ${ }^{13} \mathrm{C}\left\{{ }^{1} \mathrm{H}\right\}$ NMR (150 MHz CD $\left.{ }_{3} \mathrm{OD}\right)$ : [Table 1, Fig. S1-S17]. 
Atisinium (2): White powder; melting point $306-308{ }^{\circ} \mathrm{C}$; $[\alpha] \mathrm{D}^{20}$ : -56.66 (c $\left.0.03, \mathrm{MeOH}\right)$. UV/Vis $\lambda_{\max } \mathrm{nm}(\mathrm{MeOH})\left(\varepsilon ; \mathrm{M}^{-1} \mathrm{~cm}^{-1}\right): 205$ (63.57). IR (ZnSe) $\nu_{\max }\left(\mathrm{cm}^{-1}\right): 3375,3263,3115$, 3045, 2929, 2860, 2301, 1708, 1598, 1450, 1402, 1255, 1058, 893, 661. ${ }^{1} \mathrm{H}$ NMR (600 MHz, Methanol-d4) $\delta 8.77(\mathrm{~s}, 1 \mathrm{H}), 5.11(\mathrm{t}, J=1.8 \mathrm{~Hz}, 1 \mathrm{H}), 5.07(\mathrm{t}, J=1.8 \mathrm{~Hz}, 1 \mathrm{H}), 4.27(\mathrm{~m}, 1 \mathrm{H})$, $4.18(\mathrm{~m}, 1 \mathrm{H}), 4.04(\mathrm{~m}, 1 \mathrm{H}), 3.97(\mathrm{~m}, 1 \mathrm{H}), 3.84(\mathrm{~m}, 1 \mathrm{H}), 3.75(\mathrm{~m}, 1 \mathrm{H}), 3.70(\mathrm{~m}, 1 \mathrm{H}), 2.41(\mathrm{~m}$, 1H), $2.18(\mathrm{~m}, 1 \mathrm{H}), 2.08(\mathrm{~m}, 1 \mathrm{H}), 1.92(\mathrm{~m}, 1 \mathrm{H}), 1.87(\mathrm{~m}, 1 \mathrm{H}), 1.78-1.71(\mathrm{~m}, 4 \mathrm{H}), 1.61(\mathrm{~m}, 1 \mathrm{H})$, $1.59(\mathrm{~m}, 1 \mathrm{H}), 1.49(\mathrm{~m}, 1 \mathrm{H}), 1.39(\mathrm{~m}, 1 \mathrm{H}), 1.36(\mathrm{~m}, 1 \mathrm{H}), 1.34-1.32(\mathrm{~m}, 1 \mathrm{H}), 1.29(\mathrm{~m}, 1 \mathrm{H})$ $1.20(\mathrm{~m}, 1 \mathrm{H}), 1.14(\mathrm{~m}, 1 \mathrm{H}), 1.08(\mathrm{~s}, 3 \mathrm{H}), 1.00(\mathrm{~m}, 1 \mathrm{H}) .{ }^{13} \mathrm{C}\left\{{ }^{1} \mathrm{H}\right\} \mathrm{NMR}(150 \mathrm{MHz}, \mathrm{MeOD}) \delta$ 184.1, 156.0, 110.5, 76.0, 65.1, 60.6, 58.7, 47.5, 46.3, 42.0, 40.9, 38.7, 37.1, 35.9, 34.5, 31.7, 28.9, 26.7, 26.4, 25.0, 20.6, 20.3 [Table S1; Fig. S18-S28].

4-Oxabicyclo [3.2.2] nona-1(7),5,8-triene (3): off white powder; melting point $95-98{ }^{\circ} \mathrm{C}$. UV/Vis $\lambda_{\max } \mathrm{nm}(\mathrm{MeOH})\left(\varepsilon ; \mathrm{M}^{-1} \mathrm{~cm}^{-1}\right): 255$ (31.45), 223 (89.32) and 203 (97.12). IR (ZnSe) $v_{\max }\left(\mathrm{cm}^{-1}\right): 3390,3168,2952,2802,1670,1592,1228,1013,815$. HRMS-ESI: $m / z$ 121.0646) $[\mathrm{M}+\mathrm{H}]^{+}$(calculated 121.0648). ${ }^{1} \mathrm{H}$ NMR $(600 \mathrm{MHz}$, Methanol-d4) $\delta 7.01(\mathrm{~d}, J=8.4 \mathrm{~Hz}, 2 \mathrm{H})$, $6.68(\mathrm{~d}, J=9.0 \mathrm{~Hz}, 2 \mathrm{H}), 3.66(\mathrm{t}, J=7.2 \mathrm{~Hz}, 2 \mathrm{H}), 2.70(\mathrm{t}, J=7.2 \mathrm{~Hz}, 2 \mathrm{H}) .{ }^{13} \mathrm{C}\{1 \mathrm{H}\} \mathrm{NMR}(150$ MHz, MeOD) $\delta$ 156.7, 131.0, 130.8, 116.1, 64.5, 39.4. (Govindan et al., 2019) [Fig. S29-S33]. Atisinium cinnamate (4): Light brown powder; melting point $212-214{ }^{\circ} \mathrm{C} .[\alpha]_{\mathrm{D}} 20$ : -60.00 (c 0.03, MeOH) UV/Vis $\lambda_{\max } \mathrm{nm}(\mathrm{MeOH})\left(\varepsilon ; \mathrm{M}^{1} \mathrm{~cm}^{-1}\right): 266$ (24.85) and 205 (95.18). IR (ZnSe) $v_{\max }\left(\mathrm{cm}^{-1}\right): 3428,3370,3293,2910,2858,1638,1578,1356,1081,987$. HRMS-ESI: $m / z\left[\mathrm{M}^{+}\right]$ 344.2581 [M] $]^{+}$(calculated 344.2579) ${ }^{1} \mathrm{H}$ NMR (600 MHz, CD $\left.3 \mathrm{OD}\right)$ and ${ }^{13} \mathrm{C}\left\{{ }^{1} \mathrm{H}\right\} \mathrm{NMR}(150$ $\left.\mathrm{MHz} \mathrm{CD}_{3} \mathrm{OD}\right)$ : [Table SI; Fig. S34-S47].

Aconitic acid (5): White powder; melting point $185-187^{\circ} \mathrm{C}$. UV/Vis $\lambda_{\max } \mathrm{nm}(\mathrm{MeOH}) \mathrm{nm}(\varepsilon$, $\left.\log ; \mathrm{M}^{-1} \mathrm{~cm}^{-1}\right): 206$ (90.96). IR (ZnSe) $v_{\max }\left(\mathrm{cm}^{-1}\right): 2952,2809,1686,1679,1664,1656,1511$ 1400, 1208, 895. ESI-MS 173.17 [M-H].$~{ }^{1} \mathrm{H}$ NMR (600 MHz, Methanol-d4) $\delta 6.90$ (s, 1H), 
$3.88(\mathrm{~s}, 2 \mathrm{H}) .{ }^{13} \mathrm{C}\left\{{ }^{1} \mathrm{H}\right\}$ NMR $(150 \mathrm{MHz}, \mathrm{MeOD}) \delta 173.8,169.1,168.4,141.6,130.4,33.7$.

(Dona et al., 2016; Yin at al., 2019) [Fig. S48-S52].

Atisinium formate (6): Brown powder; melting point $198-200^{\circ}$ C. $[\alpha] \mathrm{D}^{20}$ : -43.00 (c 0.03 , $\mathrm{MeOH}) \mathrm{UV} / \mathrm{Vis} \lambda_{\max } \mathrm{nm}(\mathrm{MeOH})\left(\varepsilon ; \mathrm{M}^{-1} \mathrm{~cm}^{-1}\right): 203$ (173.54). IR (ZnSe) $v_{\max }\left(\mathrm{cm}^{-1}\right): 3259$, 2929, 2866, 1666, 1587, 1450, 1376, 1057, 1043, 868. HRMS-ESI: $m / z\left[\mathrm{M}^{+}\right] 344.2583\left[\mathrm{M}^{+}\right.$ (calculated 344.2579). ${ }^{1} \mathrm{H}$ NMR (600 MHz, CD $\mathrm{CD}_{3} \mathrm{OD}$ and ${ }^{13} \mathrm{C}\left\{{ }^{1} \mathrm{H}\right\} \mathrm{NMR}\left(150 \mathrm{MHz} \mathrm{CD}_{3} \mathrm{OD}\right)$; [Table SI; Fig. S53-S63]

\subsection{In-vitro anti-plasmodial activity}

Fig. 4 depicts the growth inhibition curves for fractions and the pure 2-O-cinnamoyl hetisine (1) obtained from A. heterohyllum roots. Among the parent extract, fractions and isolated molecules $(\mathbf{1}, \mathbf{2}, \mathbf{3}, \mathbf{5}$ and $\mathbf{6})$ evaluated for activity, the chloroform fraction and 2-O-cinnamoyl hetisine (1) purified from it stood apart for their high potency against both the drug sensitive (3D7) and the drug resistant (INDO) strains of malaria parasite in culture. With special reference to these potent samples, it may be noted that they were fairly harmless to the mammalian cell lines (bottom two panels) giving them good selectivity.

Table 2 depicts the precise $\mathrm{IC}_{50 \text { s }}$ against the parasite strains, $\mathrm{CC}_{50 \mathrm{~s}}$ against the mammalian cell lines, Resistance Indices and Selectivity Indices for all fractions and the pure 2-O-cinnamoyl hetisine isolated from the chloroform fraction. It is clear that among the different fractions, it was the chloroform fraction alone which was found to have a good activity against both the chloroquine sensitive Pf 3D7 ( $\left.\mathrm{IC}_{50} 1.32 \mu \mathrm{g} / \mathrm{ml}\right)$ and the chloroquine resistant $P f$ INDO $\left(\mathrm{IC}_{50}\right.$ $1.01 \mu \mathrm{g} / \mathrm{ml}$ ) strains of malaria parasite giving a resistance index (RI) of 0.76. Among the pure molecules 2-O-cinnamoyl hetisine (1) isolated from chloroform fractions showed promising activity against both strains with $\mathrm{IC}_{50}$ of $0.88 \mu \mathrm{g} / \mathrm{ml}(1.92 \mu \mathrm{M})$ against the chloroquine resistant Pf INDO and $4.96 \mu \mathrm{g} / \mathrm{ml}(10.8 \mu \mathrm{M})$ against the chloroquine sensitive $P f 3$ 7 giving a RI of 
0.177. The fourfold swing in RI from 0.76 for the crude chloroform extract to 0.177 for the 2$O$-cinnamoyl hetisine isolated from the extract demands deeper investigation.

\subsection{Optimization of chromatographic conditions}

In order to optimize the chromatographic conditions, a mixture of standard solution and parent root extract was taken. Different combinations of mobile phase such as acetonitrile-water $(0.1 \%$ and $0.05 \%$ formic acid), methanol-water, acetonitrile-water and different column temperatures were used for chromatographic scouting to identify the best UHPLC conditions. Reproducible retention times and symmetric peak shapes were achieved with acetonitrile$0.1 \%$ formic acid /water at column temperature $30^{\circ} \mathrm{C}$ and a flow rate of $0.30 \mathrm{~mL} / \mathrm{min}$.

\subsection{UHPLC method validation}

The correlation coefficient $\left(\mathrm{r}^{2}\right)$ of all the compounds was $>0.997$ showing good linearity of the developed method. LOD for six analytes was observed between $0.01-1.58 \mu \mathrm{g} / \mathrm{mL}$ while LOQ was found to lie between $0.04-5.21 \mu \mathrm{g} / \mathrm{mL}$. The relative standard deviation (RSD) values of 0.02-2.16 and 0.29-1.48 were observed for intra-day $(n=3)$ and inter-day $(n=6)$ precisions, respectively. The recoveries of all six analytes were observed in range of 81.22-110.69\% which showed that the developed method was sensitive, precise and accurate for quantification.

\subsection{Quantitative analysis}

Developed method was utilized for quantification of six different phytometabolites obtained from extract and fractions of root tubers of A. heterophyllum (Fig. 2, table 1). Each compound was analysed at its particular $\lambda_{\max }$ (Fig. S64-S68). Quantitative analysis revealed that all six molecules were quantifiable in parent extract, chloroform and $n$-butanol fractions whereas 2$O$-cinnamoyl hetisine (1) and cinnamic acid were absent in ethyl acetate and water fractions. Aconitic acid was also not quantified in ethyl acetate fraction. Atisinium (2) was present in good amount in all the analysed samples hence it can be regarded as major marker compound 
in this plant. Antiplasmodial potential of chloroform fraction was further validated by quantitative analysis due to presence of higher concentration of 2-O-cinnamoyl hetisine $(\mathbf{1})(\cong$ $200 \mathrm{mg} / \mathrm{g}$ ) which showed potent activity while in other fractions its concentration was found to be $\leq 2 \mathrm{mg} / \mathrm{g}$.

\section{Discussion}

Phytochemical investigation on A. heterophyllum was performed to provide scientific evidence for its traditionally claimed anti-malarial potential. Hydroethanolic extract $(1: 1 \mathrm{v} / \mathrm{v})$ was subjected to fractionation followed by silica gel column chromatography for isolation of pure molecules (Fig. 1). Phytochemical analysis resulted in isolation of six different molecules including a new diterpenoid alkaloid 2-O-cinnamoyl hetisine (1) and compounds (4 and 6) possessing new counter ions attached to atisinium ion. Parent extract, fractions and pure molecules were evaluated for their anti-plasmodial potential against the chloroquine resistant ( $P f$ INDO) and chloroquine sensitive ( $P f$ 3D7) strains. Among fractions chloroform fraction was found most active with $\mathrm{IC}_{50}$ value of 1.01 and $1.32 \mu \mathrm{g} / \mathrm{mL}$ against $P f$ INDO and $P f$ 3D7 strains, respectively. Among the isolated molecules, 2-O-cinnamoyl hetisine (1) showed promising antiplasmodial activity with $\mathrm{IC}_{50}$ of $1.92 \mu \mathrm{M}$ and $10.8 \mu \mathrm{M}$ against $P f$ INDO and $P f$ 3D7 strains, respectively (Table 2). Diterpenoid alkaloids with complex structural, multiple stereocenters, and unique biosynthesis could be responsible for the pharmacological activities of this plant (Shen et al., 2020).

Despite high commercial importance and demand, there has been a lack of quality control method for this plant which can be used for quality assurance and quantification of isolated molecules. So, by following ICH guidelines, a UHPLC-DAD based quantification method was developed for simultaneous quantification of six molecules including three isolated molecules $(\mathbf{1}, \mathbf{2}, \mathbf{5})$ and three commercially available standards (S1, S2, S3) (Fig. 2, Table 3 and 4). 
Quantification results further validated the anti-plasmodial potential of chloroform fraction due to presence of higher concentration of $2-O$-cinnamoyl hetisine $(1)(\cong 200 \mathrm{mg} / \mathrm{g})$ as compared to other fractions $(<2 \mathrm{mg} / \mathrm{g})$. On the basis of quantification and anti-plasmodial results, we can say that atisinium (2) molecule can be regarded as marker compound of this plant because of its high concentration in all extracts and fractions whereas 2-O-cinnamoyl hetisine (1) as biomarker as it showed promising antiplasmodial activity. The developed quantification method can also be used as quality assessment tool for differentiating the roots of $A$. heterophyllum from its substitutes Cyperus rotundus and Cryptocoryne spiralis.

\section{Conclusion}

The present study concludes that structurally complex diterpenoid alkaloids are endowed with antiplasmodial activity which provides a scientific basis for the traditional use of this plant for anti-malarial purpose. The developed UHPLC-DAD based method can further be used for quality assessment and for detection of adulterants in commercially available samples of this plant.

\section{Contributions}

Anmol, Kumari S and Singh R carried out extraction, fractionation and isolation. Anmol, Kumar $\mathrm{R}$ and Sharma $\mathrm{U}$ did the structural elucidation of isolated molecules. Agrawal $\mathrm{P}$ performed the experiment on antiplasmodial activity. Sharma U and Sahal D designed and coordinated the whole study. UHPLC-DAD based quantification was carried out by Anmol and Aggarwal G under the supervision of Sharma U. Manuscript is drafted and finalized by Anmol, Sharma U, and Sahal D. All authors read and approved the final manuscript.

\section{Declaration of competing interest}

Authors report no conflict of interest. 


\section{Acknowledgment}

Authors are grateful to the Director, CSIR-IHBT for continuous encouragement. This research is supported by CSIR, New Delhi, India (MLP0159). Anmol is thankful to DST for INSPIRE fellowship. Ms. Surekha Kumari and Raman Singh acknowledges CSIR, New Delhi, India for research fellowship. CSIR-IHBT communication no. for this manuscript is 0000.

\section{References}

Ahmad, S.S., 2007. Medicinal wild plants from Lahore-Islamabad motorway (M-2). Pak. J. Bot. $39,355-375$.

Bhatt, V., Kumari, S., Upadhyay, P., Agrawal, P., Anmol, Sahal, D., Sharma, U., 2020. Chemical profiling and quantification of potential active constituents responsible for the antiplasmodial activity of Cissampelos pareira. J. Ethnopharmacol. 262, 113185.

Bora, P.S., Suresh, P.S., Kumari, S., Anmol, Puri, S., Sharma, U. 2021. Integrated Approach for the Quality Assurance of Commercially Important Himalayan Medicinal Plants. In Medicinal Plants. Springer, Cham. 721-768

Dona, A.C., Kyriakides, M., Scott, F., Shephard, E.A., Varshavi, D., Veselkov, K., Everett, J. R., 2016. A guide to the identification of metabolites in NMR-based metabonomics/metabolomics experiments. Comput. Struct. Biotechnol. J. 14, 135-153

Feleke, S.M., Reichert, E.N., Mohammed, H., Brhane, B.G., Mekete, K., Mamo, H., Petros, B., Solomon, H., Abate, E., Hennelly, C. Denton, M., Keeler, C., Hathaway, N.J., Juliano, J.J., Bailey, J.A., Rogier, E., Cunningham, J., Aydemir, O., Parr, J.B., 2021. 
Plasmodium falciparum is evolving to escape malaria rapid diagnostic tests in Ethiopia. Nat. Microbiol. 6, 1289-1299.

Govindan, B., Johnson, A.J., Viswanathan, G., Ramaswamy, V., Koshy, K.C., Baby, S., 2019. Secondary metabolites from the unique bamboo, Melocanna baccifera. Nat. Prod. Res. $33,122-125$.

Holzmeyer, L., Hartig, A.K., Franke, K., Brandt, W., Muellner-Riehl, A.N., Wessjohann, L.A., Schnitzler, J., 2020. Evaluation of plant sources for antiinfective lead compound discovery by correlating phylogenetic, spatial, and bioactivity data. PNAS 117, 1244412451.

Huang, S., Zhang, J.F., Chen, L., Gao, F., Zhou, X.L., 2020. Diterpenoid alkaloids from Aconitum anthoroideum that offer protection against MPP+-Induced apoptosis of SHSY5Y cells and acetylcholinesterase inhibitory activity. Phytochemistry 178, 112459.

Jabeen, N., Shawl, A.S., Dar, G.H., Sultan, P., 2006. Callus induction and organogenesis from explants of Aconitum heterophyllum medicinal plant. Biotechnology 5, 287-291

Joshi, V.K., Joshi, A., Dhiman, K.S., 2017. The Ayurvedic Pharmacopoeia of India, development and perspectives. J. Ethnopharmacol. 197, 32-38.

Koparde, A.A., Doijad, R.C., Magdum, C.S., 2019. Natural products in drug discovery. In: Doijad RC, editor. Pharmacognosy - Medicinal Plants. Rijeka: IntechOpen, . p. 14

Kour, G.D., Chaubey, S., Singh, D.C., Tiwari, R.C., 2016. A literary review on ativisha (Aconitum heterophyllum wall ex. Royle): An important ayurvedic drug with special reference to brihadtrayee and nighantus. Int. J. Res. Ayurveda Pharm. 7, 20-27. 
Lin, C.Z., Zhao, Z.X., Xie, S.M., Mao, J.H., Zhu, C.C., Li, X.H., Bairi, Z.D., Kangsa, S.Q., Dun, Z., Xiong, T.Q., Wu, A.Z., 2014. Diterpenoid alkaloids and flavonoids from Delphinium trichophorum. Phytochemistry, 97, 88-95.

Major Epidemics of the Modern Era. Council on Foreign Relations. 2021. https://www.cfr.org/timeline/major-epidemics-modern-era. (Accessed 18 October, 2021)

Malhotra, N., Sharma, S. 2021. Aconitum heterophyllum. In Himalayan Medicinal Plants (pp. 5-25). Academic Press.

Mosmann, T. 1983. Rapid colorimetric assay for cellular growth and survival: Application to proliferation and cytotoxicity assays. J. Immunol. Methods, 65, 55-63.

Nagarajan, M., Kuruvilla, G.R., Kumar, K.S., Venkatasubramanian, P., 2015. Abhava pratinidhi dravya: A comparative phytochemistry of Ativisha, Musta and related species. J. Ayurveda Integr. Med. 6, 53-63

Paramanick, D., Panday, R., Shukla, S.S., Sharma, V., 2017. Primary pharmacological and other important findings on the medicinal plant "Aconitum heterophyllum" (aruna). J. Pharmacopuncture, 20, 89-92.

Pascolutti, M., Quinn, R.J., 2014. Natural products as lead structures: chemical transformations to create lead-like libraries. Drug Discov. 19, 215-221.

Pelletier, S.W., and Mody, N.V., 1979. An unusual rearrangement of ajaconine: an example of a" disfavored" 5-endo-trigonal ring closure. J. Am. Chem. Soc. 101, 492-494.

Pelletier, S.W. Oeltmann, T.N., 1968. NMR studies of diterpene alkaloids. Tetrahedron 24, 2019-2038 
Pelletier, S.W., Aneja, R., Gopinath, K.W., 1968. The alkaloids of Aconitum heterophyllum Wall.: Isolation and characterization. Phytochemistry, 7(4), 625-635.

Shen, Y., Liang, W.J., Shi, Y.N., Kennelly, E.J., Zhao, D.K., 2020. Structural diversity, bioactivities, and biosynthesis of natural diterpenoid alkaloids. Nat. Prod. Rep. 37, 763796.

Sikora, K., Jaśkiewicz, M., Neubauer, D., Migoń, D., Kamysz, W. 2020. The role of counterions in peptides-An overview. Pharmaceuticals 13, 442

Smilkstein, M., Sriwilaijaroen, N., Kelly, J. X., Wilairat, P., Riscoe, M., 2004. Simple and inexpensive fluorescence-based technique for high-throughput antimalarial drug screening. Antimicrob. Agents Chemother., 48, 1803-1806.

Suresh, P. S., Gupta, S. S., Sharma, A., Sharma, U., 2020. An Overview of Coronaviruses: InSilico Approach to Decipher Anti-SARS-CoV-2 Natural Products. ChemRxiv 10.26434/chemrxiv.12782411.v1

The Ayurvedic Pharmacopoeia of India, 1st edition, Part I, Volume I. Delhi (IN): Government of India, Ministry of Health and Family Welfare, Department of Indian Systems of Medicine \& Homoeopathy (http://www.ayurveda.hu/api/API-Vol-1.pdf)

Trager, W., Jensen, J.B., 1976. Human malaria parasites in continuous culture. Science (New York, N.Y.) 193, 673-675.

Ukani, M.D., Mehta, N.K., Nanavati, D.D., 1996. Aconitum heterophyllum (ativisha) in ayurveda. Anc. Sci. Life 16, 166-171.

Veeresham, C., 2012. Natural products derived from plants as a source of drugs. J. Adv. Pharm. Technol. 3, 200-201. 
Wang, F. P., Liang, X.T., 2002. C20-diterpenoid alkaloids. In Alkaloids Chem. Biol. 59, 1280. Elsevier Science, Amsterdam.

Wangchuk, P., Bremner, J.B., Skelton, B.W., White, A.H., Rattanajak, R., Kamchonwongpaisan, S., 2010. Antiplasmodial activity of atisinium chloride from the Bhutanese medicinal plant, Aconitum orochryseum. J. Ethnopharmacol. 130, 559-562.

White, N. J. 2004. Antimalarial drug resistance. J. Clin. Investig. 113(8), 1084-1092.

$\begin{array}{lllll}\text { World malaria } & \text { report } & \text { (2021). }\end{array}$ https://www.who.int/publications/i/item/9789240015791. (Accessed 18 October 2021)

Xu, W., Chen, L., Shan, L., Gao, F., Huang, S., Zhou, X., 2016. Two new atisine-type C20diterpenoid alkaloids from Aconitum leucostomum. Heterocycles 92, 2059-2065

Yin, T., Zhou, H., Cai, L., Ding, Z., 2019. Non-alkaloidal constituents from the genus Aconitum: a review. RSC Adv. 9, 10184-10194 

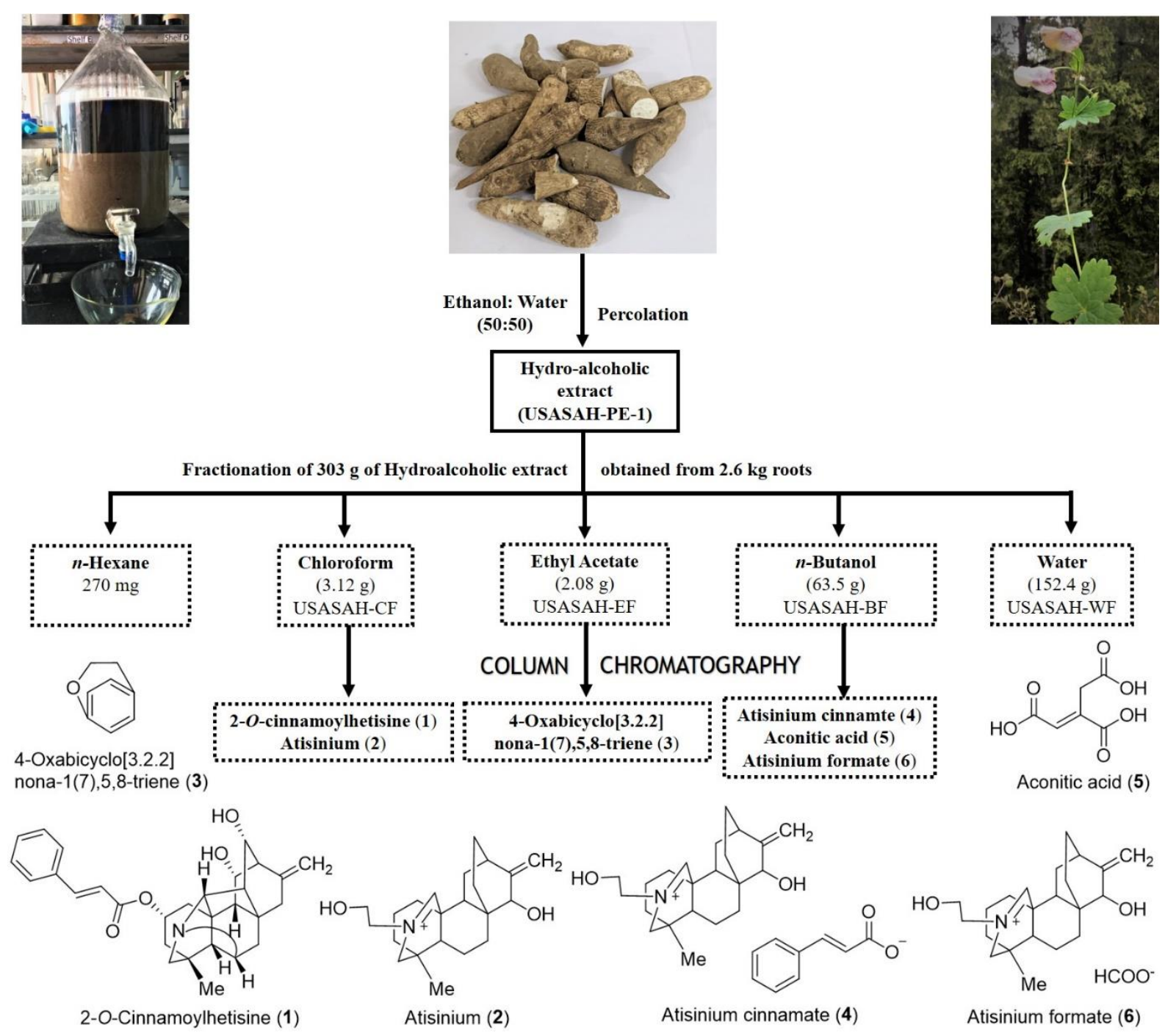

Fig. 1. Schematic representation showing extraction, fractionation and isolation of molecules from roots of A. heterophyllum. 


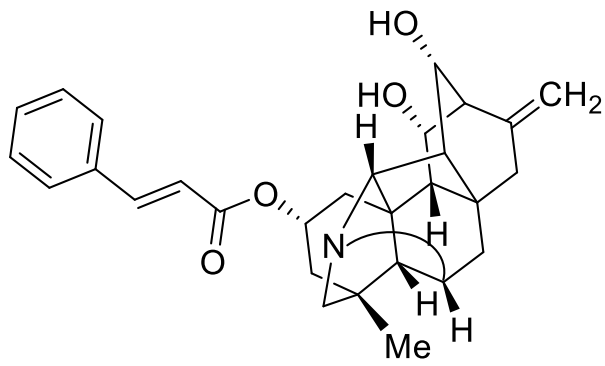

2-O-Cinnamoylhetisine (1)

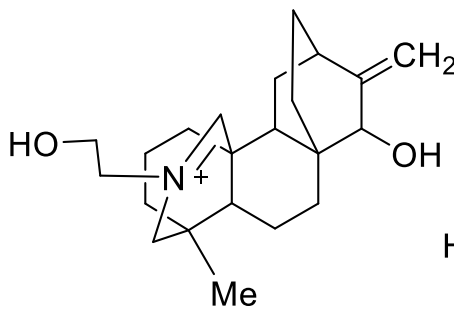

Atisinium (2)<smiles>O=C(O)C=C(CC(=O)O)C(=O)O</smiles>

Aconitic acid (5)<smiles>COc1cc(/C=C/C(=O)O[Na])ccc1O</smiles>

Fig. 2. Structure of molecules quantified in extract and fractions.

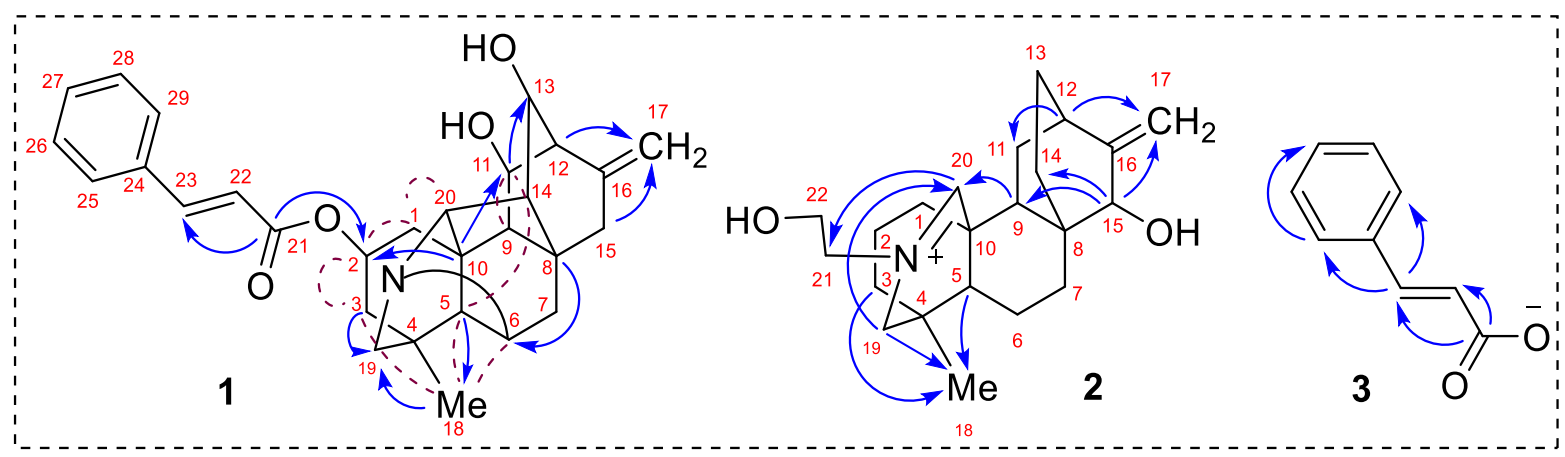

Fig. 3. Key HMBC correlations observed in 2-O-cinnamoyl hetisine (1), atisinium ion (2), cinnamate counter ion (3) are shown with blue arrow and NOESY correlation in compound $\mathbf{1}$ are shown by dashed grey lines. 

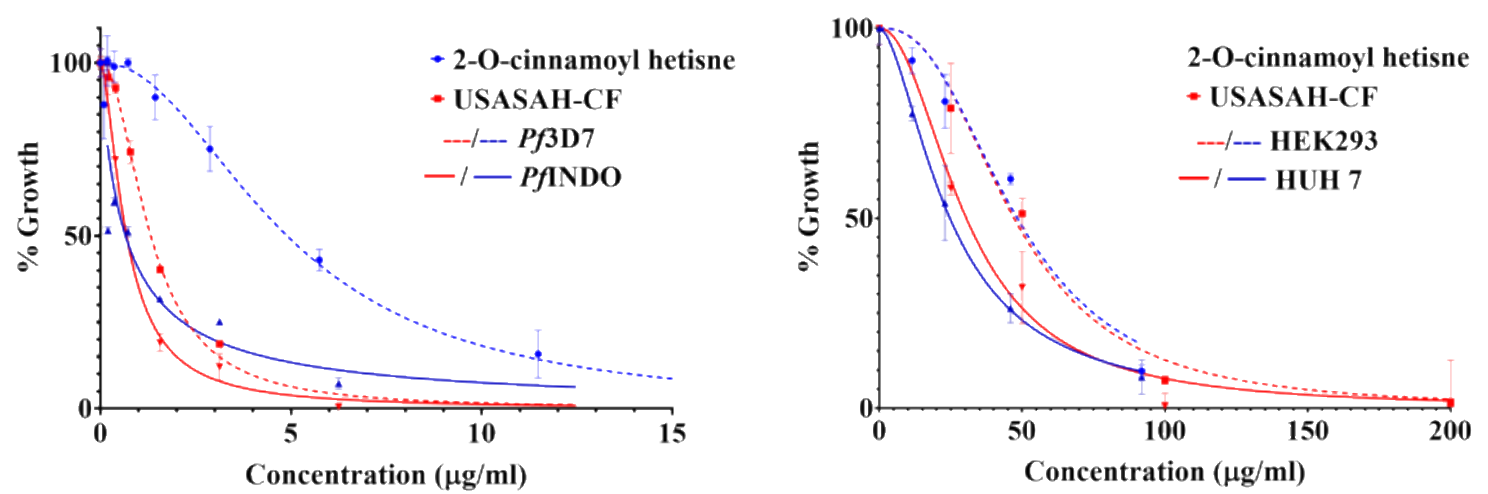

Fig. 4. Growth inhibition curves for chloroform fraction and the pure molecule [2-O-cinnamoyl hetisine (1) obtained from A. heterophyllum root. Left panel denotes inhibition profile for chloroquine sensitive ( $P f 3 D 7$ ) and chloroquine resistant ( $P f$ INDO) strain while the right panel shows their activities against human embryonic kidney (HEK293) and human liver (HUH7) cell lines. 

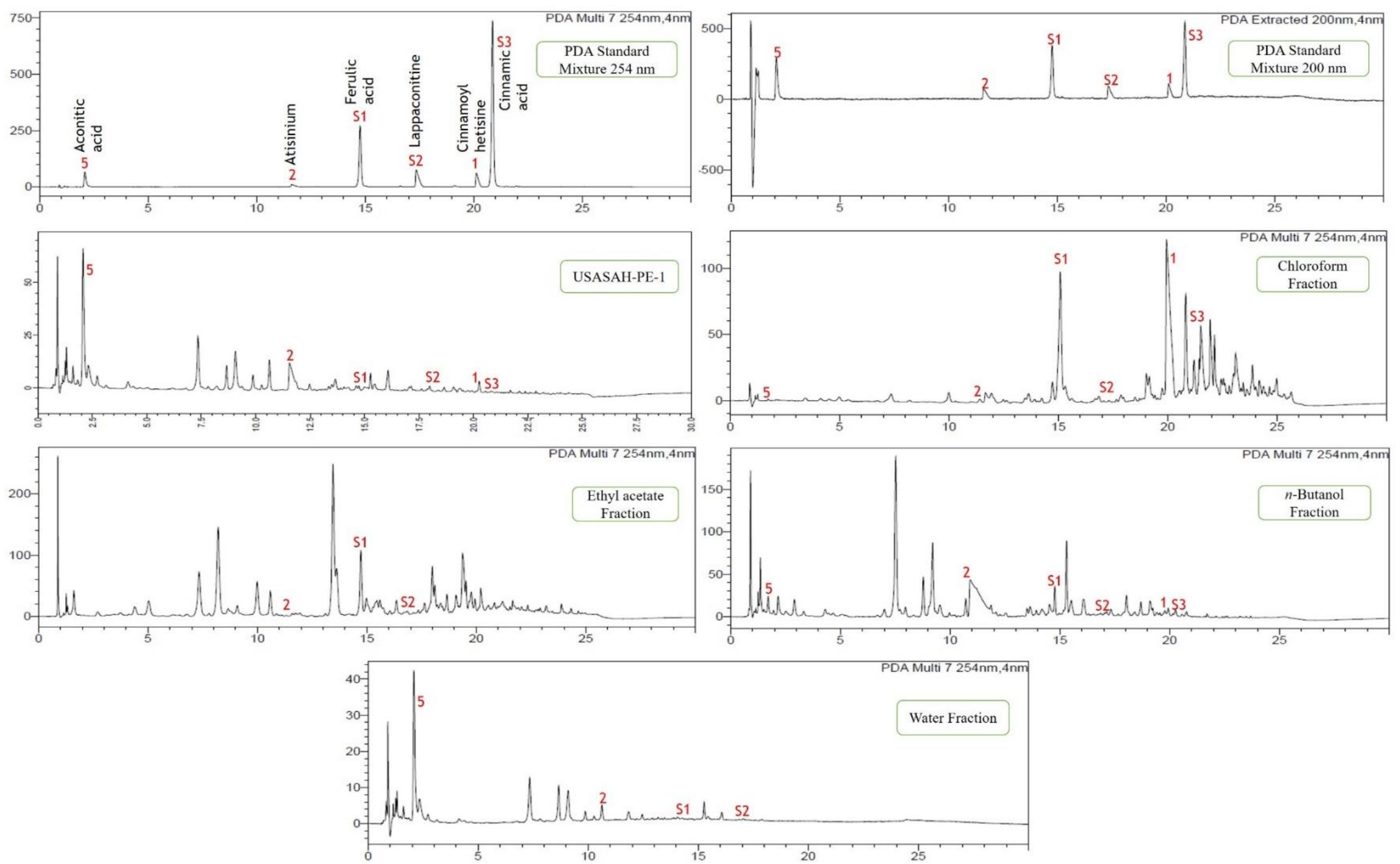

Fig. 5. UHPLC-DAD chromatograms of A. heterophyllum standard mixture, extract and fractions. 
Table1. ${ }^{1} \mathrm{H}$ and ${ }^{13} \mathrm{C}$ NMR data for molecule $\mathbf{1}$.

\begin{tabular}{|c|c|c|c|}
\hline Position & Nature of Carbon & ${ }^{13} \mathrm{C}\left(\delta_{C}\right)$ & ${ }^{1} \mathbf{H}\left(\delta_{H}\right)$ \\
\hline 1 & $\mathrm{CH}_{2}$ & 31.0 & $\begin{array}{c}3.41 \mathrm{~m} \\
1.94^{\mathrm{a}}\end{array}$ \\
\hline 2 & $\mathrm{CH}$ & 70.6 & $5.31 \mathrm{~m}$ \\
\hline 3 & $\mathrm{CH}_{2}$ & 36.9 & $\begin{array}{l}1.77 \mathrm{~m} \\
2.07^{\mathrm{a}}\end{array}$ \\
\hline 4 & $\mathrm{q}$ & 36.8 & - \\
\hline 5 & $\mathrm{CH}$ & 58.7 & $2.21 \mathrm{~m}$ \\
\hline 6 & $\mathrm{CH}$ & 66.9 & $4.11(\mathrm{br} \mathrm{s}, 1 \mathrm{H})$ \\
\hline 7 & $\mathrm{CH}_{2}$ & 35.1 & $\begin{array}{l}1.95^{\mathrm{a}} \\
1.91^{\mathrm{a}}\end{array}$ \\
\hline 8 & $q$ & 44.4 & - \\
\hline 9 & $\mathrm{CH}$ & 55.7 & $2.19 \mathrm{~m}$ \\
\hline 10 & q & 52.0 & - \\
\hline 11 & $\mathrm{CH}$ & 75.7 & $4.30(\mathrm{~d}, J=9.0 \mathrm{~Hz}, 1 \mathrm{H})$ \\
\hline 12 & $\mathrm{CH}$ & 51.8 & $2.40^{\mathrm{a}}$ \\
\hline 13 & $\mathrm{CH}$ & 71.9 & $4.15(\mathrm{~d}, J=9.0 \mathrm{~Hz}, 1 \mathrm{H})$ \\
\hline 14 & $\mathrm{CH}$ & 52.2 & $2.38^{\mathrm{a}}$ \\
\hline 15 & $\mathrm{CH}_{2}$ & 33.8 & $\begin{array}{l}2.36^{\mathrm{a}} \\
2.07^{\mathrm{a}}\end{array}$ \\
\hline 16 & $q$ & 146.8 & - \\
\hline 17 & $\mathrm{CH}_{2}$ & 108.6 & $\begin{array}{l}4.87(\text { br s, } 1 \mathrm{H}) \\
4.72(\text { br s, } 1 \mathrm{H})\end{array}$ \\
\hline 18 & $\mathrm{CH}_{3}$ & 29.1 & $1.21(\mathrm{~s}, 3 \mathrm{H})$ \\
\hline 19 & $\mathrm{CH}_{2}$ & 61.4 & $\begin{array}{l}3.08(\mathrm{~d}, J=12.0 \mathrm{~Hz}, 1 \mathrm{H}) \\
3.68(\mathrm{~d}, J=11.4 \mathrm{~Hz}, 1 \mathrm{H})\end{array}$ \\
\hline 20 & $\mathrm{CH}$ & 69.6 & $4.57($ br s, $1 \mathrm{H})$ \\
\hline 21 & $\mathrm{q}$ & 167.5 & - \\
\hline 22 & $\mathrm{CH}$ & 119.4 & $6.63(\mathrm{~d}, J=15.6 \mathrm{~Hz}, 1 \mathrm{H})$ \\
\hline 23 & $\mathrm{CH}$ & 146.4 & $7.70(\mathrm{~d}, J=16.2 \mathrm{~Hz}, 1 \mathrm{H})$ \\
\hline 24 & $\mathrm{q}$ & 135.8 & - \\
\hline 25 & $\mathrm{CH}$ & 129.3 & $7.64 \mathrm{~m}$ \\
\hline 26 & $\mathrm{CH}$ & 130.0 & $7.41 \mathrm{~m}$ \\
\hline 27 & $\mathrm{CH}$ & 131.6 & 7.41-7.40 m \\
\hline 28 & $\mathrm{CH}$ & 130.0 & $7.41 \mathrm{~m}$ \\
\hline 29 & $\mathrm{CH}$ & 129.3 & $7.64 \mathrm{~m}$ \\
\hline
\end{tabular}


Table 2. $\mathrm{IC}_{50}$ values against different strains of $P$. falciparum, resistance indices, cytotoxicity against mammalian cell line and selectivity indices of extracts, fractions and isolated molecules.

\begin{tabular}{|c|c|c|c|c|c|c|c|}
\hline \multirow{2}{*}{$\begin{array}{c}\text { Samples } \\
\text { USASAH=X }\end{array}$} & \multicolumn{2}{|c|}{$\mathrm{IC}_{50}(\mu \mathrm{g} / \mathrm{ml})$} & \multirow{2}{*}{$\begin{array}{l}\text { Resistance } \\
\text { Index }\end{array}$} & \multicolumn{2}{|c|}{$\mathrm{CC}_{50}(\mu \mathrm{g} / \mathrm{ml})$} & \multicolumn{2}{|c|}{ Selectivity index } \\
\hline & $P f$ INDO & Pf 3D7 & & HEK 293 & HUH 7 & $\begin{array}{c}\text { HEK } \\
\text { 293/INDO }\end{array}$ & $\begin{array}{c}\text { HUH } \\
\text { 7/INDO }\end{array}$ \\
\hline X-PE-1 & \multicolumn{2}{|c|}{$>100$} & * & \multicolumn{2}{|c|}{$>400$} & \multicolumn{2}{|c|}{ * } \\
\hline $\mathbf{X}-\mathbf{C F}$ & $1.01 \pm 0.28$ & $1.32 \pm 0.04$ & 0.76 & $47.14 \pm 2.56$ & $30.44 \pm 2.14$ & 46.67 & 30.13 \\
\hline X-EF & \multirow{3}{*}{\multicolumn{2}{|c|}{ * }} & \multirow{3}{*}{ * } & 289.5 & 113.48 & \multirow{3}{*}{\multicolumn{2}{|c|}{ * }} \\
\hline $\mathbf{X}-\mathbf{B F}$ & & & & \multirow{2}{*}{\multicolumn{2}{|c|}{$>400$}} & & \\
\hline $\mathbf{X}-\mathbf{W F}$ & & & & & & & \\
\hline $\begin{array}{l}\text { 2-O-cinnamoyl } \\
\text { hetisine }\end{array}$ & $0.88 \pm 0.07$ & $4.96 \pm 0.59$ & 0.17 & $48.26 \pm 5.58$ & $24.59 \pm 2.49$ & 54.84 & 27.94 \\
\hline
\end{tabular}

*: $\mathrm{CC}_{50}$ and SI have not been determined for those samples that have $\mathrm{IC}_{50}>25 \mu \mathrm{g} / \mathrm{ml}$. USASAH-PE-1 = ethanol: water $(1: 1)$, CF $=\mathrm{Chloroform}$ fraction, $\mathrm{EF}=$ Ethyl acetate fraction, $\mathrm{BF}=$ butanol fraction, $\mathrm{WF}=$ water fraction 
Table 3. Regression equations, linear ranges, LOD, LOQ, intra-day, inter-day and recovery study for compounds quantified in the roots of $A$. heterophyllum.

\begin{tabular}{|c|c|c|c|c|c|c|c|c|c|c|c|}
\hline \multirow[b]{2}{*}{ Analyte } & \multirow[b]{2}{*}{$\begin{array}{c}\text { Regression } \\
\text { equation }^{\mathrm{a}}\end{array}$} & \multirow[b]{2}{*}{$\mathbf{R}^{2}$} & \multirow{2}{*}{$\begin{array}{c}\text { Linear } \\
\text { range } \\
(\mu \mathrm{g} / \mathrm{mL})\end{array}$} & \multirow[b]{2}{*}{$\begin{array}{c}\mathbf{L O D}^{\mathrm{b}} \\
(\mu \mathrm{g} / \mathrm{mL})\end{array}$} & \multirow[b]{2}{*}{$\begin{array}{c}\mathbf{L O Q}^{\mathbf{c}} \\
(\mu \mathrm{g} / \mathrm{mL})\end{array}$} & \multirow{2}{*}{$\begin{array}{c}\text { Intra-day }^{d} \\
\text { RSD (\%) } \\
\text { n=6 }\end{array}$} & \multirow{2}{*}{$\begin{array}{c}\text { Inter-day } \\
\text { RSD (\%) } \\
\text { n=3 }\end{array}$} & \multicolumn{4}{|c|}{ Recovery $^{\mathrm{e}}$} \\
\hline & & & & & & & & $\begin{array}{c}\text { Original } \\
(\mu \mathrm{g})\end{array}$ & $\begin{array}{c}\text { Spiked } \\
(\mu \mathrm{g})\end{array}$ & $\begin{array}{l}\text { Detected } \\
(\mu \mathrm{g})\end{array}$ & $\begin{array}{c}\text { Average } \\
\text { Recovery } \\
(\%)\end{array}$ \\
\hline $\begin{array}{l}\text { 2-O-cinnamoyl } \\
\text { hetisine }(\mathbf{1})\end{array}$ & $\begin{array}{c}\mathrm{Y}= \\
=6536.67 \mathrm{X}- \\
7814.20\end{array}$ & 0.999 & $\begin{array}{l}0.16- \\
83.33\end{array}$ & 0.05 & 0.16 & 0.26 & 0.41 & 2.39 & $\begin{array}{l}2 \\
4 \\
6 \\
8 \\
\end{array}$ & $\begin{array}{l}4.10 \\
6.07 \\
7.91 \\
9.85 \\
\end{array}$ & 90.72 \\
\hline Atisinium (2) & $\begin{array}{c}\mathrm{Y}= \\
=4404.79 \mathrm{X}- \\
12976.1\end{array}$ & 0.997 & $\begin{array}{l}5.21- \\
83.33\end{array}$ & 1.58 & 5.21 & 1.07 & 0.49 & 255.68 & $\begin{array}{c}45.45 \\
90.91 \\
136.36 \\
181.82\end{array}$ & $\begin{array}{l}300.51 \\
353.01 \\
390.09 \\
436.50\end{array}$ & 101.11 \\
\hline $\begin{array}{c}\text { Aconitic acid } \\
(\mathbf{5})\end{array}$ & $\begin{array}{c}\mathrm{Y}=14046.7 \mathrm{X}- \\
38391.3\end{array}$ & 0.997 & $\begin{array}{l}2.60- \\
83.33\end{array}$ & 0.79 & 2.60 & 2.16 & 0.29 & 5.246 & $\begin{array}{c}4.55 \\
9.09 \\
13.64 \\
18.18 \\
\end{array}$ & $\begin{array}{l}10.31 \\
15.09 \\
20.39 \\
25.38 \\
\end{array}$ & 110.69 \\
\hline $\begin{array}{l}\text { Ferulic acid } \\
\quad(\text { S1) }\end{array}$ & $\begin{array}{c}\mathrm{Y}=30337.6 \mathrm{X}- \\
29923.2\end{array}$ & 0.999 & $\begin{array}{l}0.04- \\
83.33\end{array}$ & 0.01 & 0.04 & 1.58 & 1.48 & 2.18 & $\begin{array}{l}2 \\
4 \\
6 \\
8\end{array}$ & $\begin{array}{l}3.65 \\
5.48 \\
7.17 \\
9.02\end{array}$ & 81.22 \\
\hline $\begin{array}{l}\text { Lappaconitine } \\
\text { (S2) }\end{array}$ & $\begin{array}{c}Y=1474.68 X- \\
2910.29\end{array}$ & 0.999 & $\begin{array}{l}0.65- \\
83.33\end{array}$ & 0.20 & 0.65 & 0.55 & 0.34 & 4.25 & $\begin{array}{l}2 \\
4 \\
6 \\
8\end{array}$ & $\begin{array}{c}5.91 \\
7.67 \\
9.34 \\
11.31\end{array}$ & 85.40 \\
\hline $\begin{array}{l}\text { Cinnamic acid } \\
(\mathbf{S 3})\end{array}$ & $\begin{array}{c}\mathrm{Y}=55740.3 \mathrm{X}- \\
50628.6\end{array}$ & 0.999 & $\begin{array}{l}0.04- \\
83.33\end{array}$ & 0.01 & 0.04 & 0.02 & 0.80 & 0 & $\begin{array}{l}2 \\
4 \\
6 \\
8\end{array}$ & $\begin{array}{l}2.23 \\
4.23 \\
5.91 \\
7.82\end{array}$ & 103.34 \\
\hline
\end{tabular}

${ }^{a}$ The regression equations were presented as $\mathrm{Y}=\mathrm{mX}+\mathrm{C}$. $\mathrm{Y}$ and $\mathrm{X}$ were defined as peak area and concentration of compound, respectively. 
${ }^{\mathrm{b}} \mathrm{LOD}$, limit of detection, $\mathrm{S} / \mathrm{N}=3$.

${ }^{\mathrm{c}} \mathrm{LOQ}$, limit of quantification, $\mathrm{S} / \mathrm{N}=10$.

${ }^{\mathrm{d}}$ Intra and inter-day precision was determined on the basis of peak area. RSD $(\%)=(\mathrm{SD} /$ mean $) \times 100$.

${ }^{\mathrm{e}}$ Recovery $(\%)=($ detected amount - original amount $) /$ spiked amount $\times 100$.

Table 4. Amount $(\mathrm{mg} / \mathrm{g} \pm \mathrm{SD})$ of compounds in different extracts and fractions of A. heterophyllum.

\begin{tabular}{|c|c|c|c|c|c|c|}
\hline Sample & $\begin{array}{l}\text { 2-O-cinnamoyl hetisine } \\
(1)\end{array}$ & Atisinium (2) & $\begin{array}{c}\text { Aconitic acid } \\
(5)\end{array}$ & $\begin{array}{c}\text { Ferulic acid } \\
\text { (S1) }\end{array}$ & $\begin{array}{c}\text { Lappaconitine } \\
(\text { S2) }\end{array}$ & $\begin{array}{c}\text { Cinnamic acid } \\
(\mathbf{S 3})\end{array}$ \\
\hline USASAH-PE-1 & $2.0 \pm 0.01$ & $64.9 \pm 2.08$ & $20.9 \pm 0.22$ & $0.5 \pm 0.00$ & $1.1 \pm 0.03$ & $0.1 \pm 0.01$ \\
\hline USASAH-CF & $200.2 \pm 0.88$ & $44.2 \pm 0.13$ & $1.1 \pm 0.08$ & $5.8 \pm 0.02$ & $2.9 \pm 0.05$ & $4.6 \pm 0.03$ \\
\hline USASAH-EF & - & $18.7 \pm 2.39$ & - & $21.0 \pm 0.06$ & $20.3 \pm 0.13$ & - \\
\hline USASAH-BF & $0.2 \pm 0.00$ & $302.1 \pm 3.26$ & $2.9 \pm 0.03$ & $1.4 \pm 0.00$ & $1.0 \pm 0.01$ & $0.1 \pm 0.00$ \\
\hline USASAH-WF & - & $4.9 \pm 0.31$ & $15.2 \pm 0.27$ & $0.1 \pm 0.00$ & $0.3 \pm 0.02$ & - \\
\hline
\end{tabular}

USASAH-PE-1 = ethanol: water (1:1) extract, $\mathrm{CF}=$ Chloroform fraction, $\mathrm{EF}=$ Ethyl acetate fraction, $\mathrm{BF}=n$-Butanol fraction, $\mathrm{WF}=\mathrm{Water}$ fraction, $\mathrm{SD}$ : standard deviation; ' - ' indicates absence 